\title{
IMAGINE IT THICK IN YOUR OWN HAIR: SCULPTURES AND A UNIQUE ARTIST'S BOOK
}

\author{
HEIDE HATRY
}

We have come to accept and live with the fact that the world is seriously wounded, and even now, when it is bleeding to death before our eyes, we are largely content to put the matter into the hands of the doctors, the experts who we believe are taking care of such things.

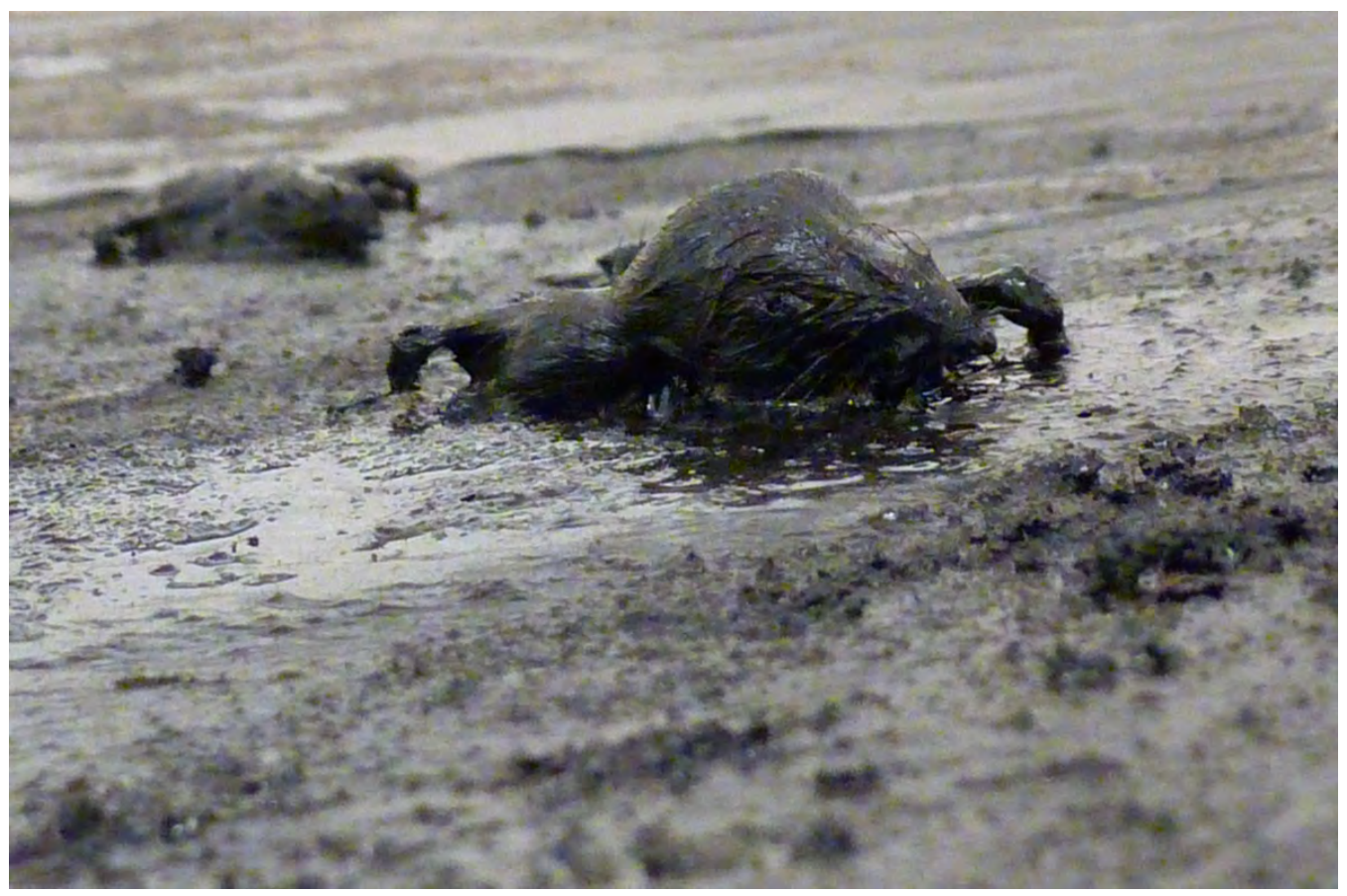


But the whole technological complex and our relationship to it, as Heidegger pointed out long ago, is the problem, not the solution. Human beings acting in human ways - concerned, involved, aware - are the solution.

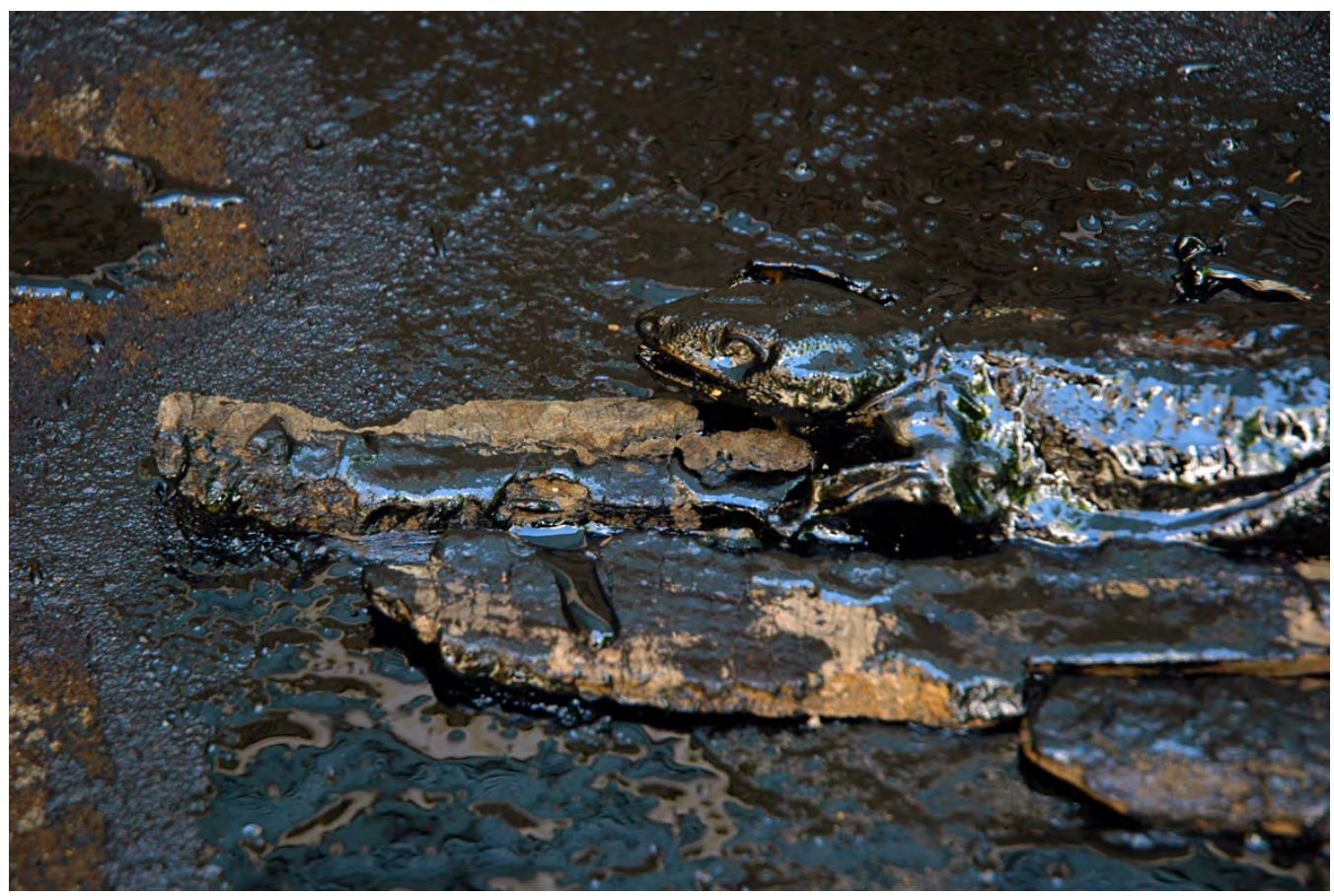

My solo benefit exhibition at Pierre Menard Gallery in Cambridge, Massachusetts - Imagine It Thick In Your Own Hair - was intended to make people aware of the tragedy and motivate them to help clean up the disaster BP created in 2010 .

Pouring oil and tar over dead birds, opossums, rats, mice, moles, or whatever I found by the side of the road or in the trash bins of pet stores, and which I had first preserved using taxidermy techniques, I created scenes of dead animals enmired in black viscosity to give viewers an intimate feeling for the way the spill in the Gulf of Mexico has doomed and destroyed wildlife. 


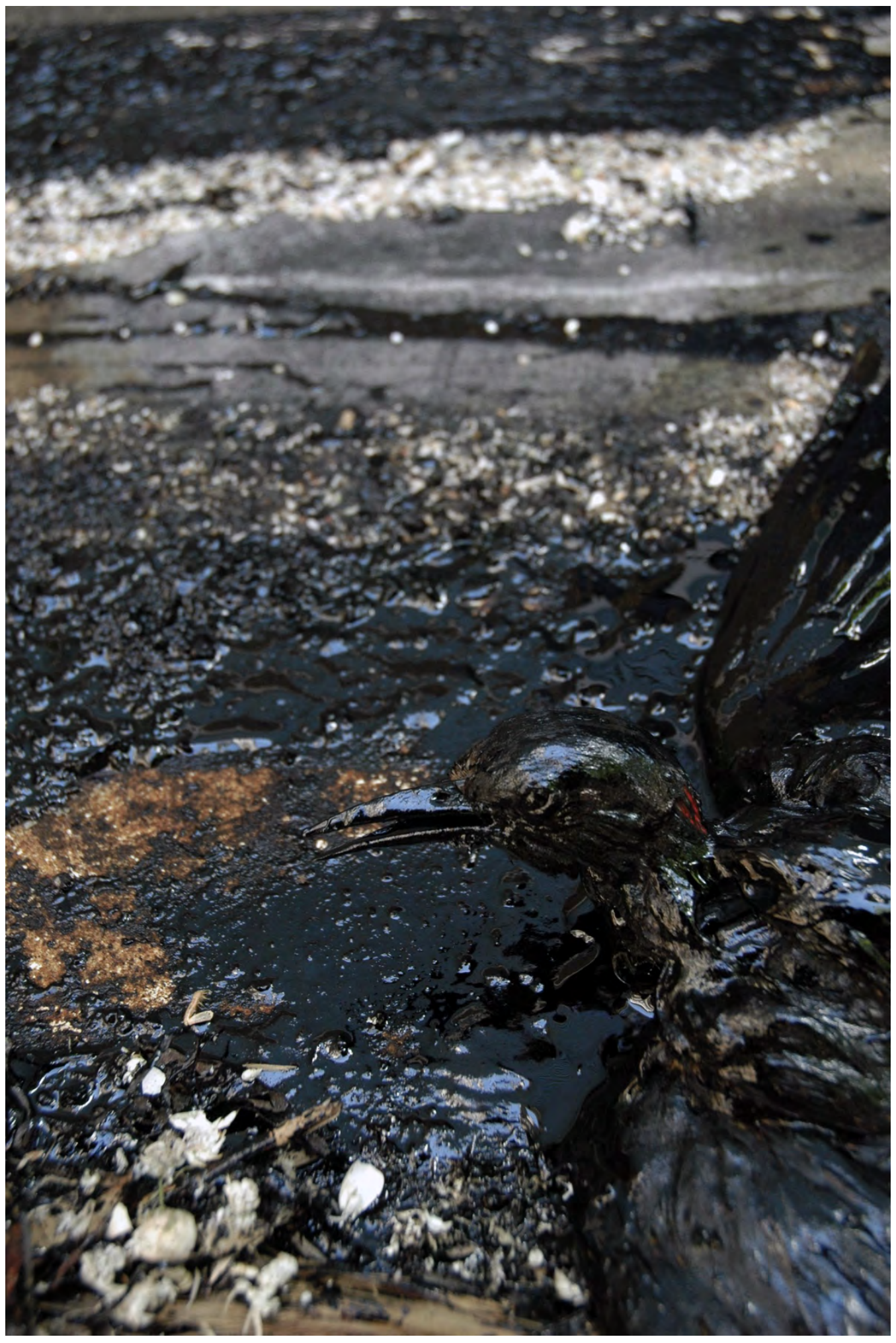


It is difficult to not look away when you see an actual animal suffering, but in showing the effects if not the process, I felt that I at least put the harsh truth as directly in front of the viewer and as unmitigated by distance as I could.

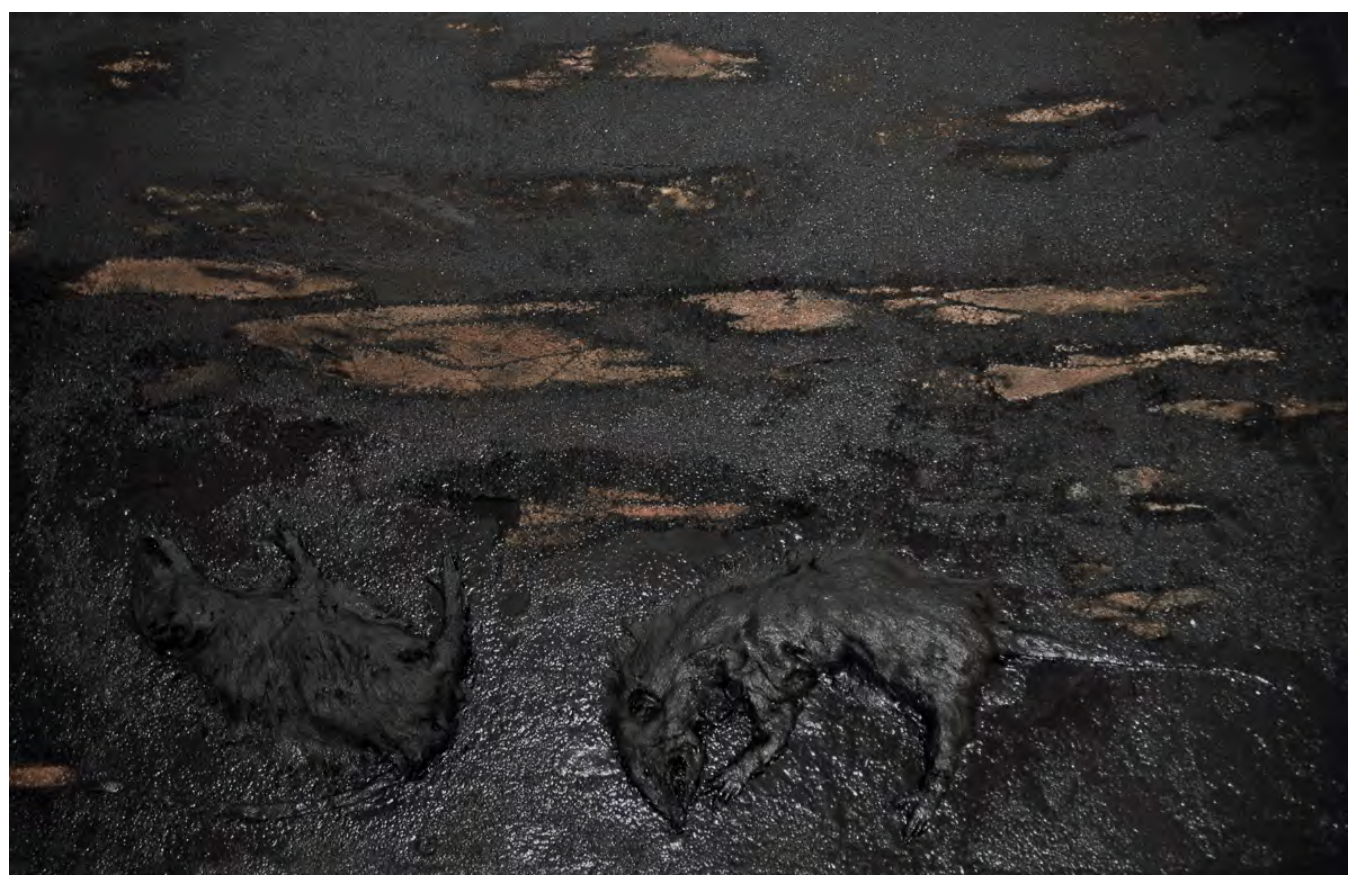

As in all my work, my materials were animals that had already diedsometimes by means that are just as ethically problematic as the mass torture and slaughter of those we raise for food and clothing, or which are collateral casualties of our greed - but I somehow feel that the fact that they have been put to some purpose, a dignified one, I hope, confers some measure of redemption upon them. 
In collaboration with Robert Kelly I made several unique artist's books. This is one of my treatments of his poem Imagine It Thick In Your Own Hair:

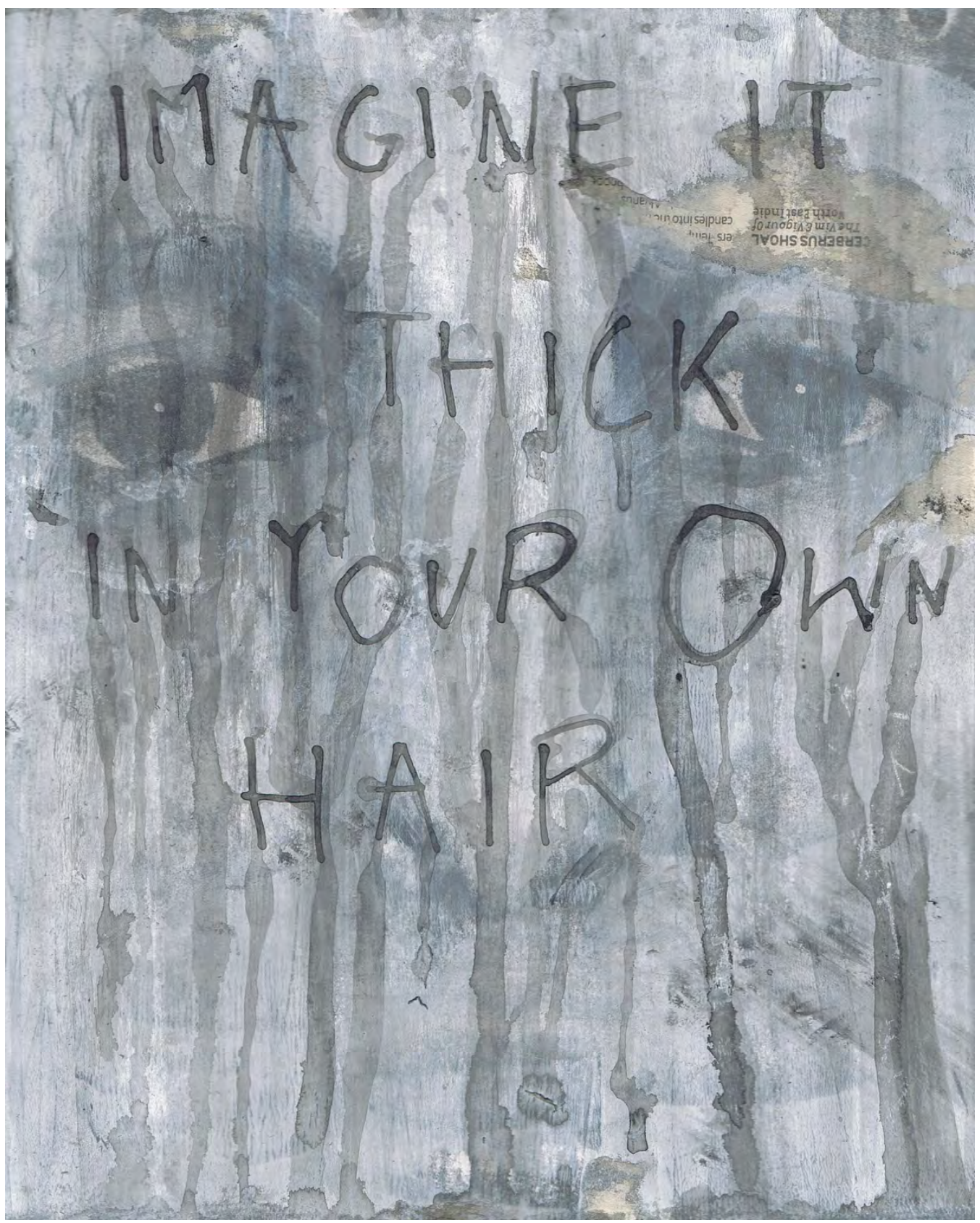




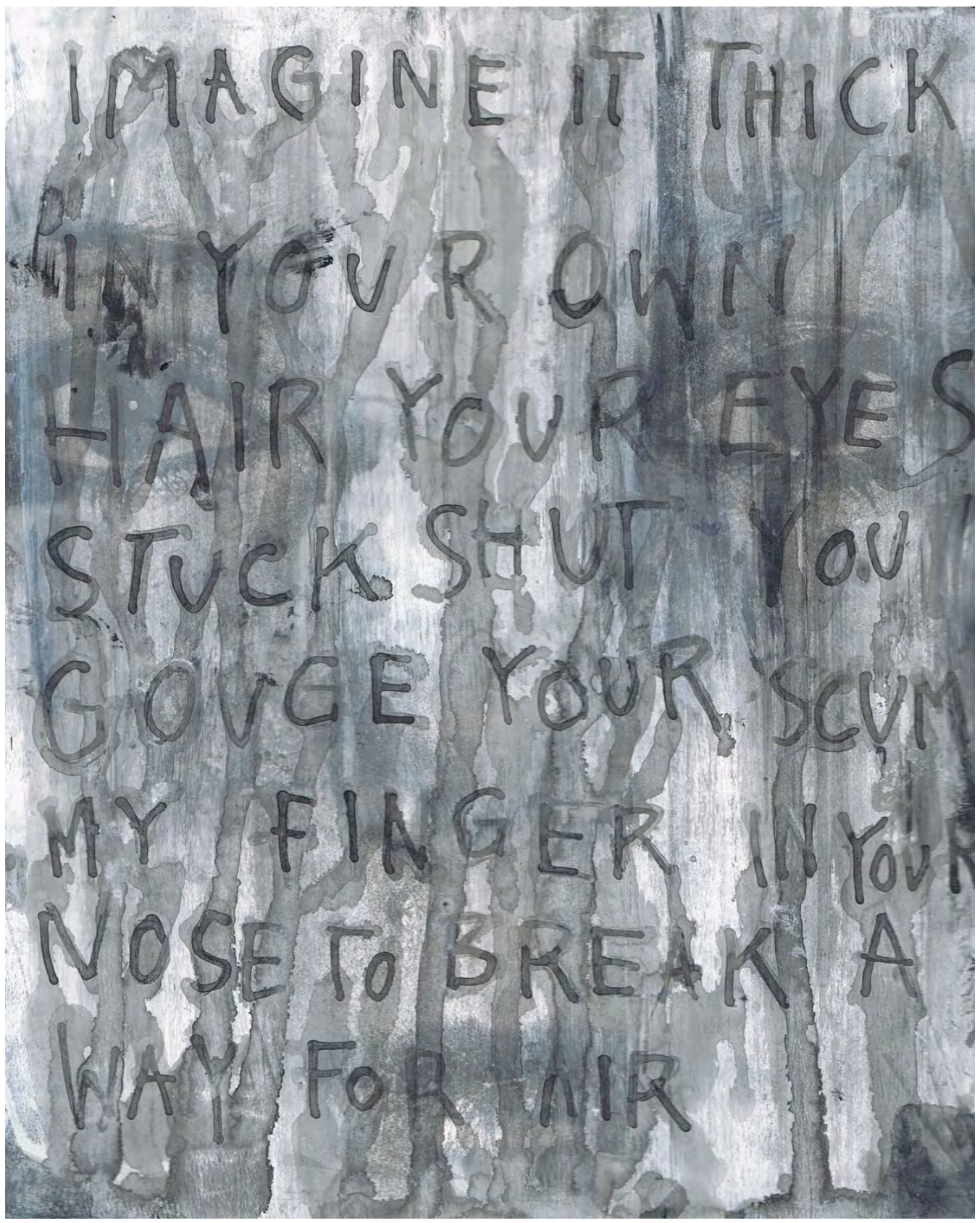




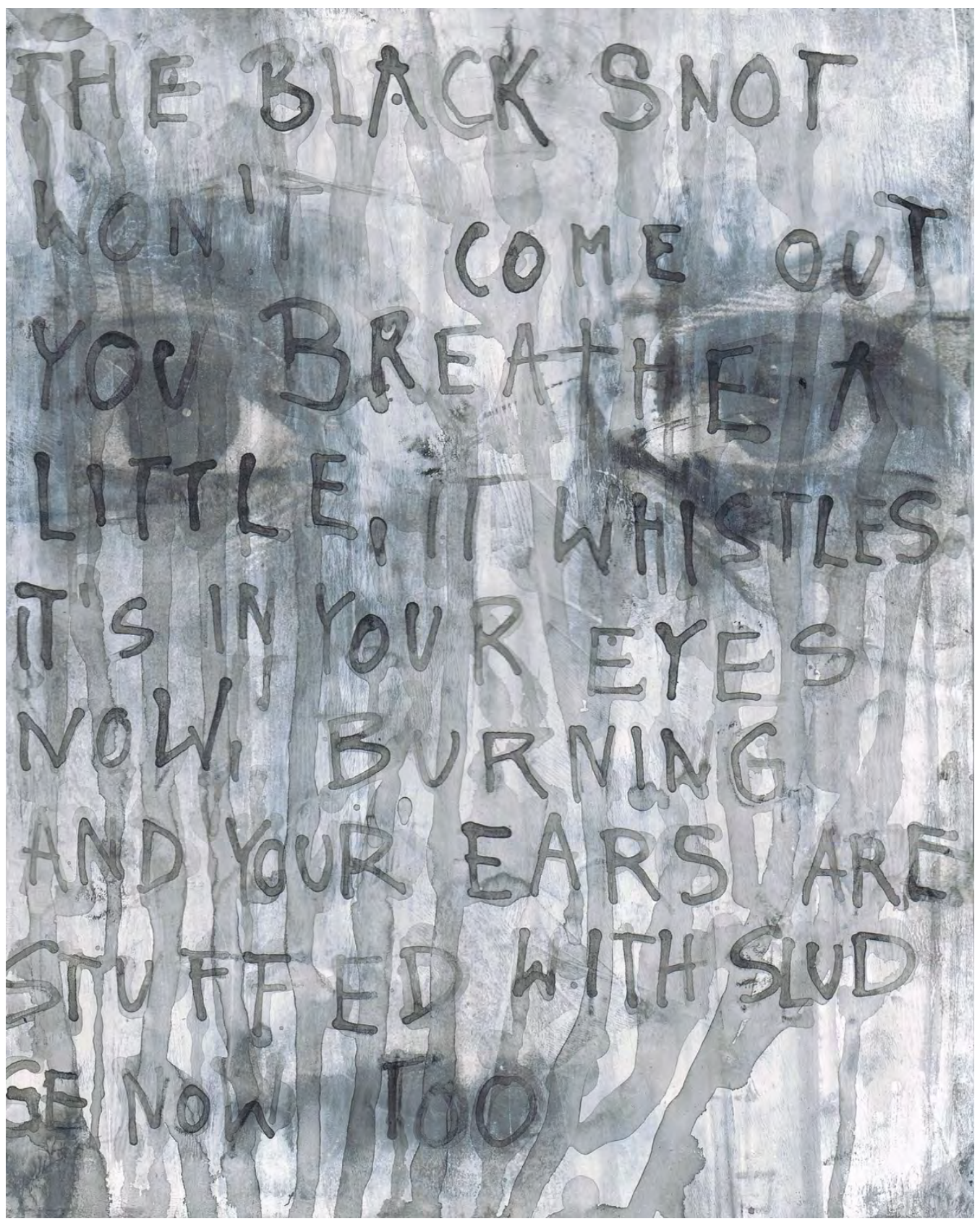




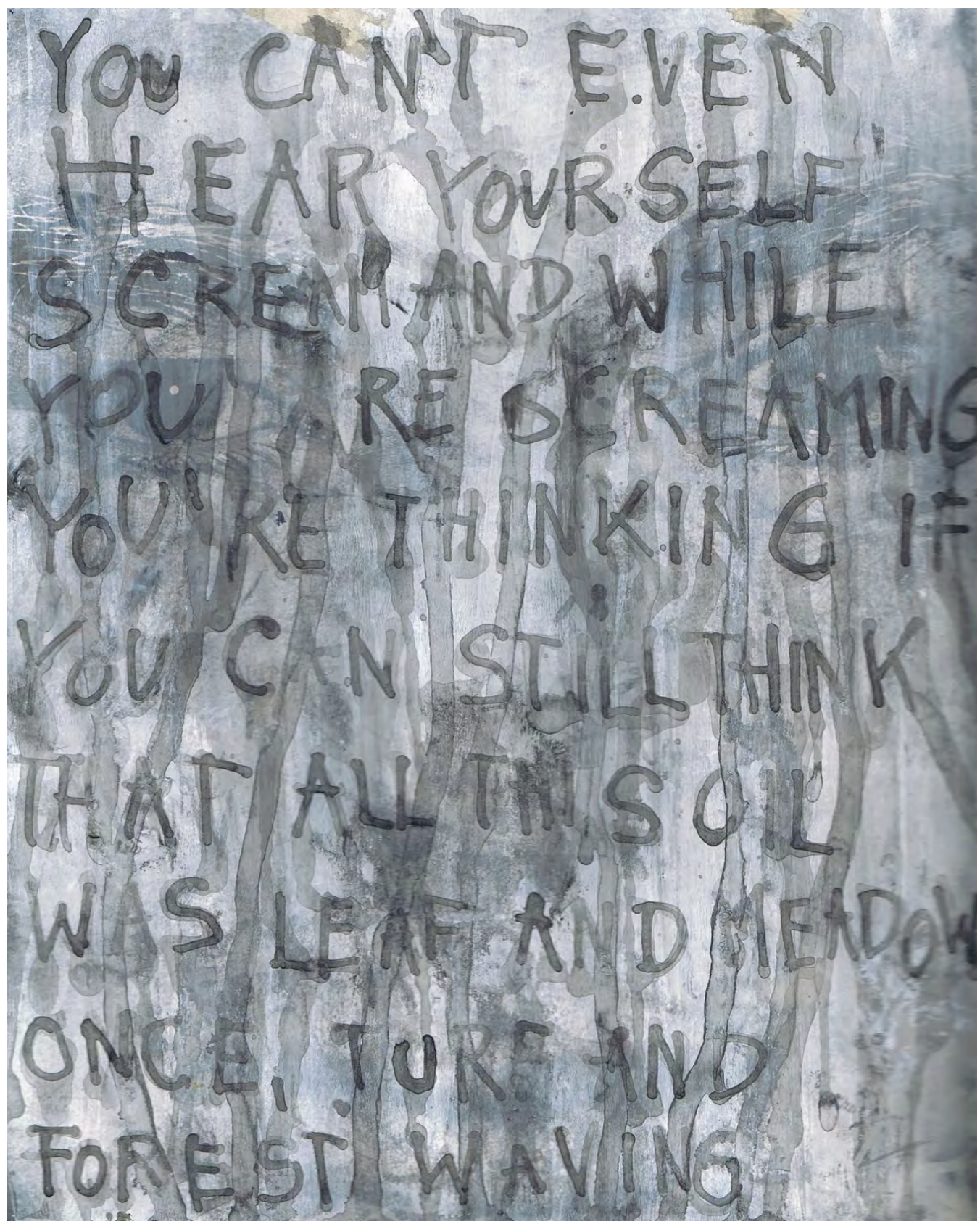




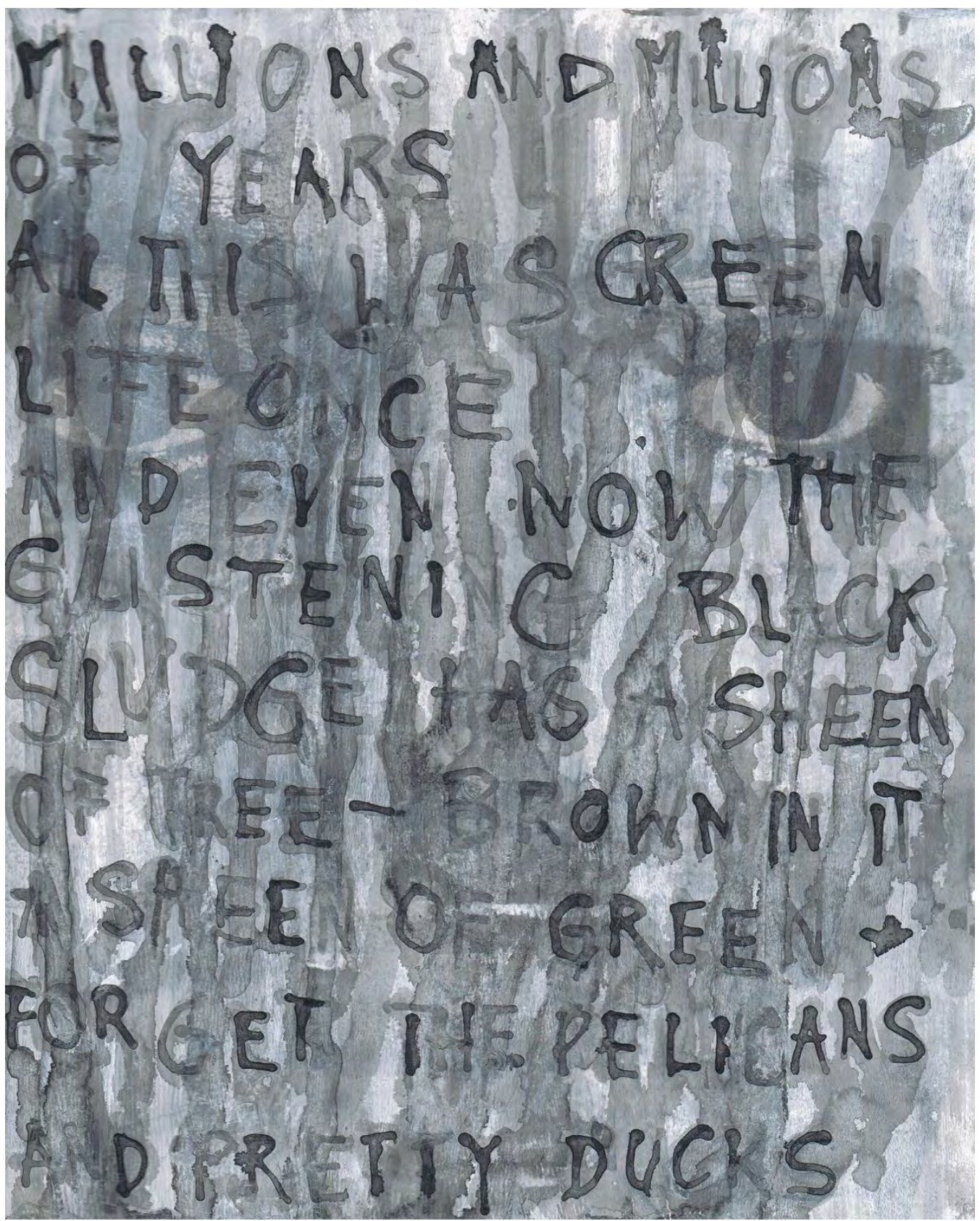




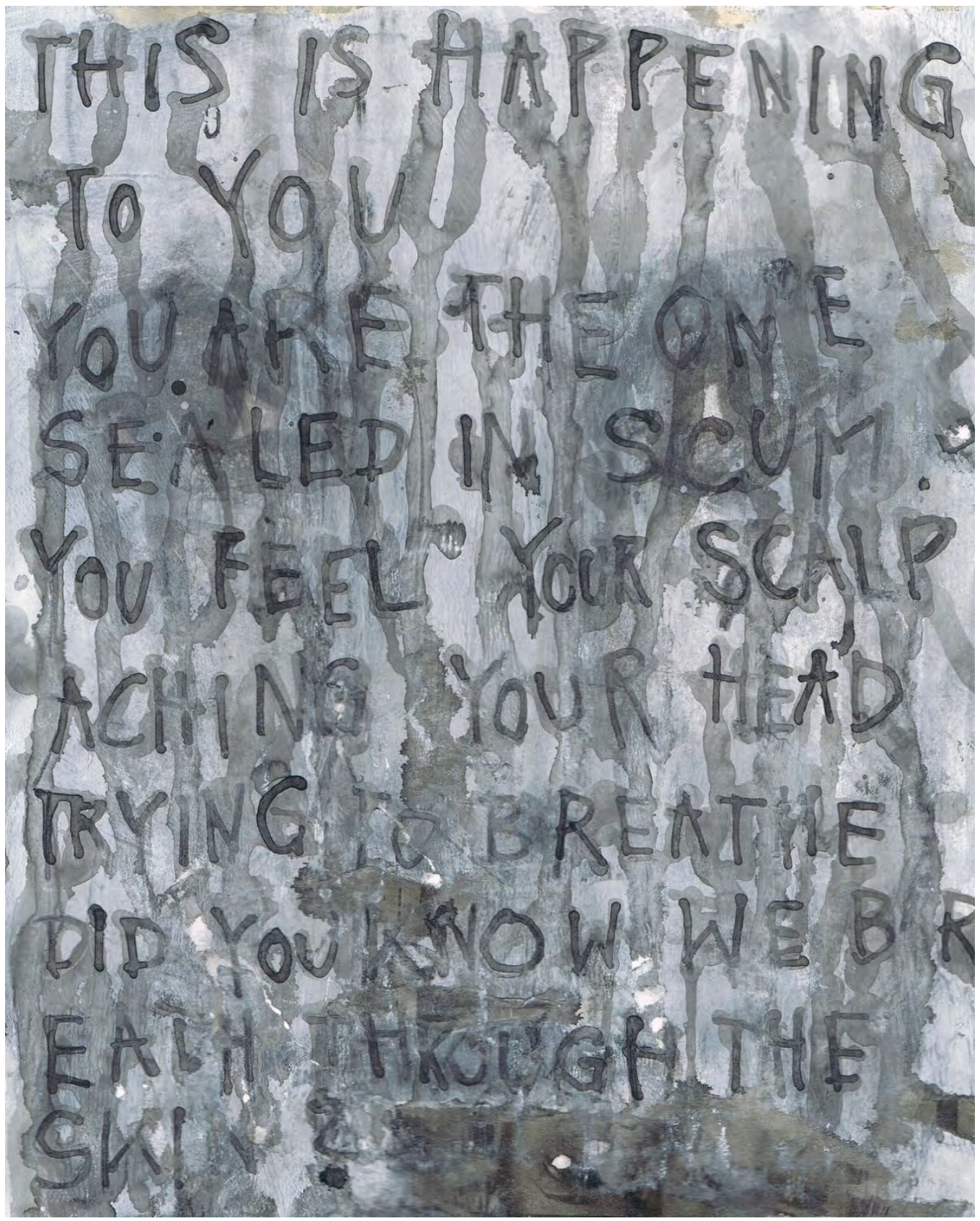




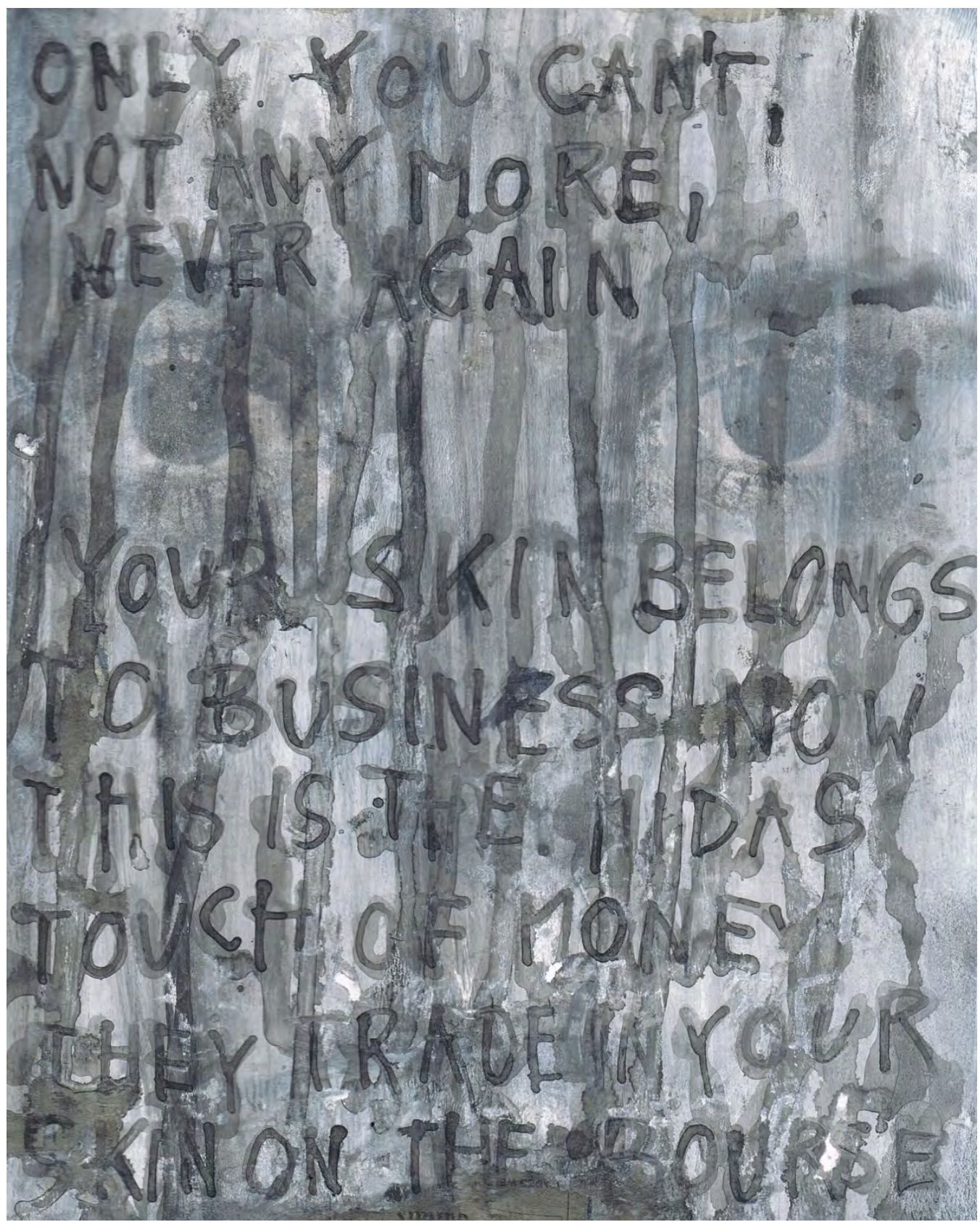




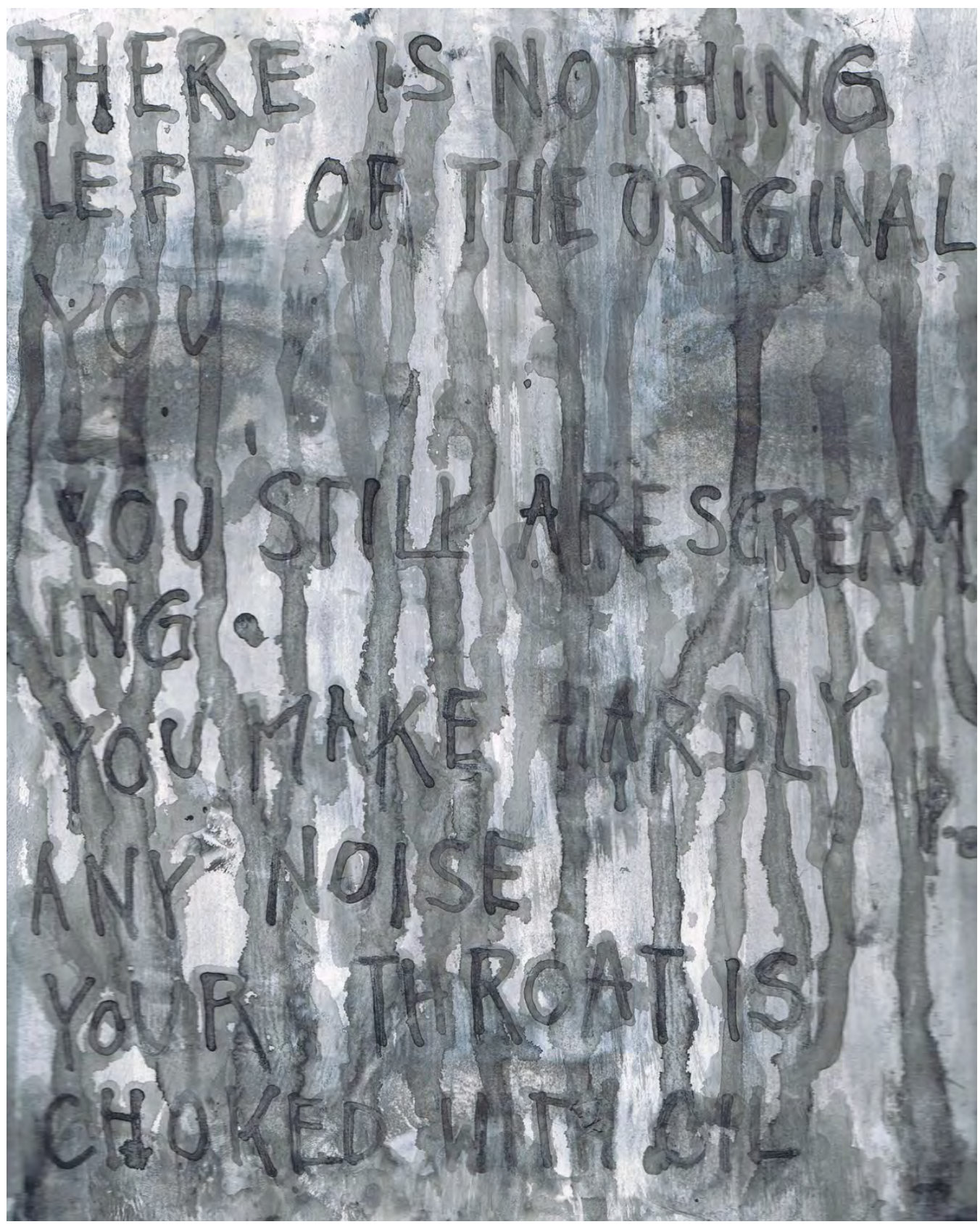




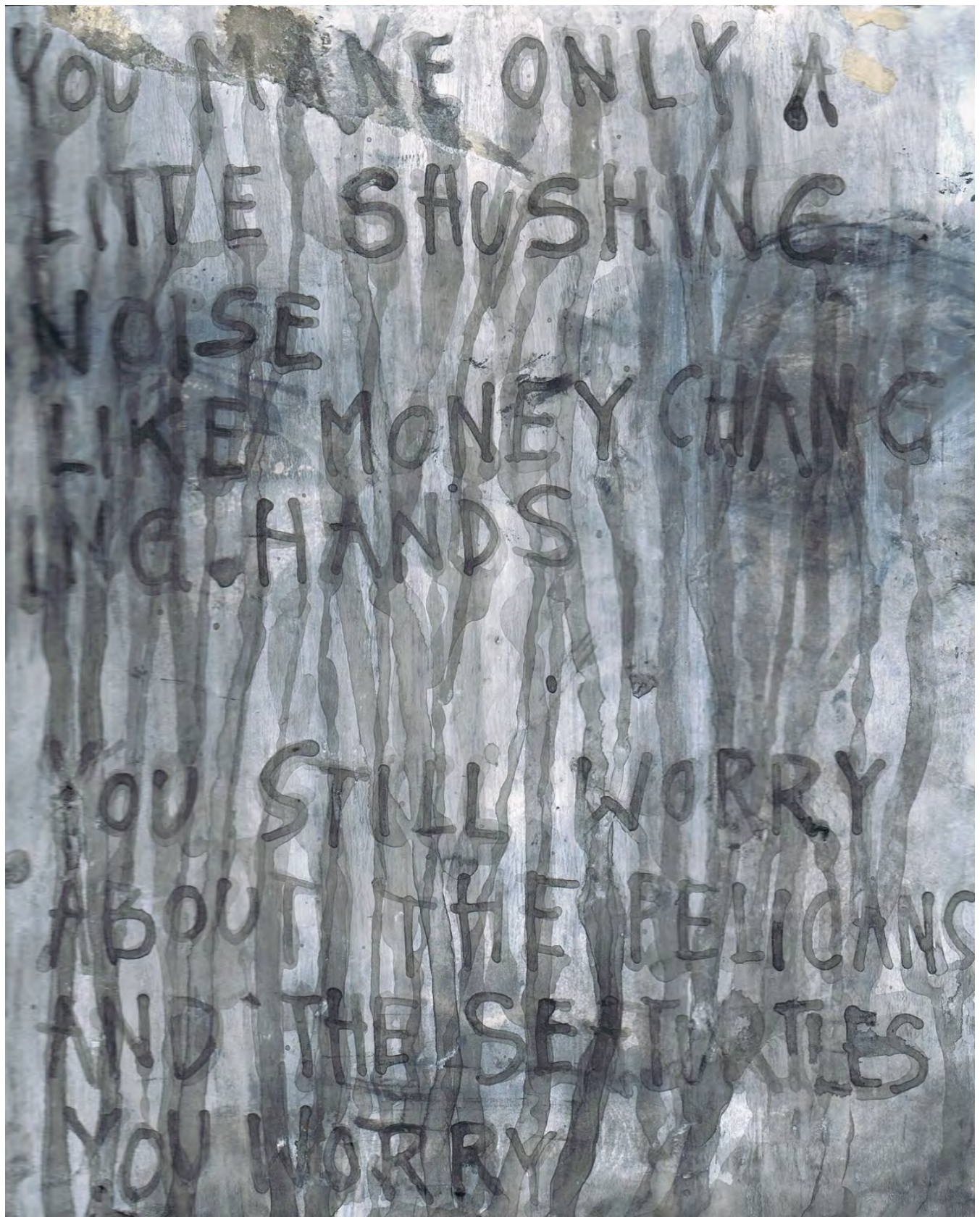




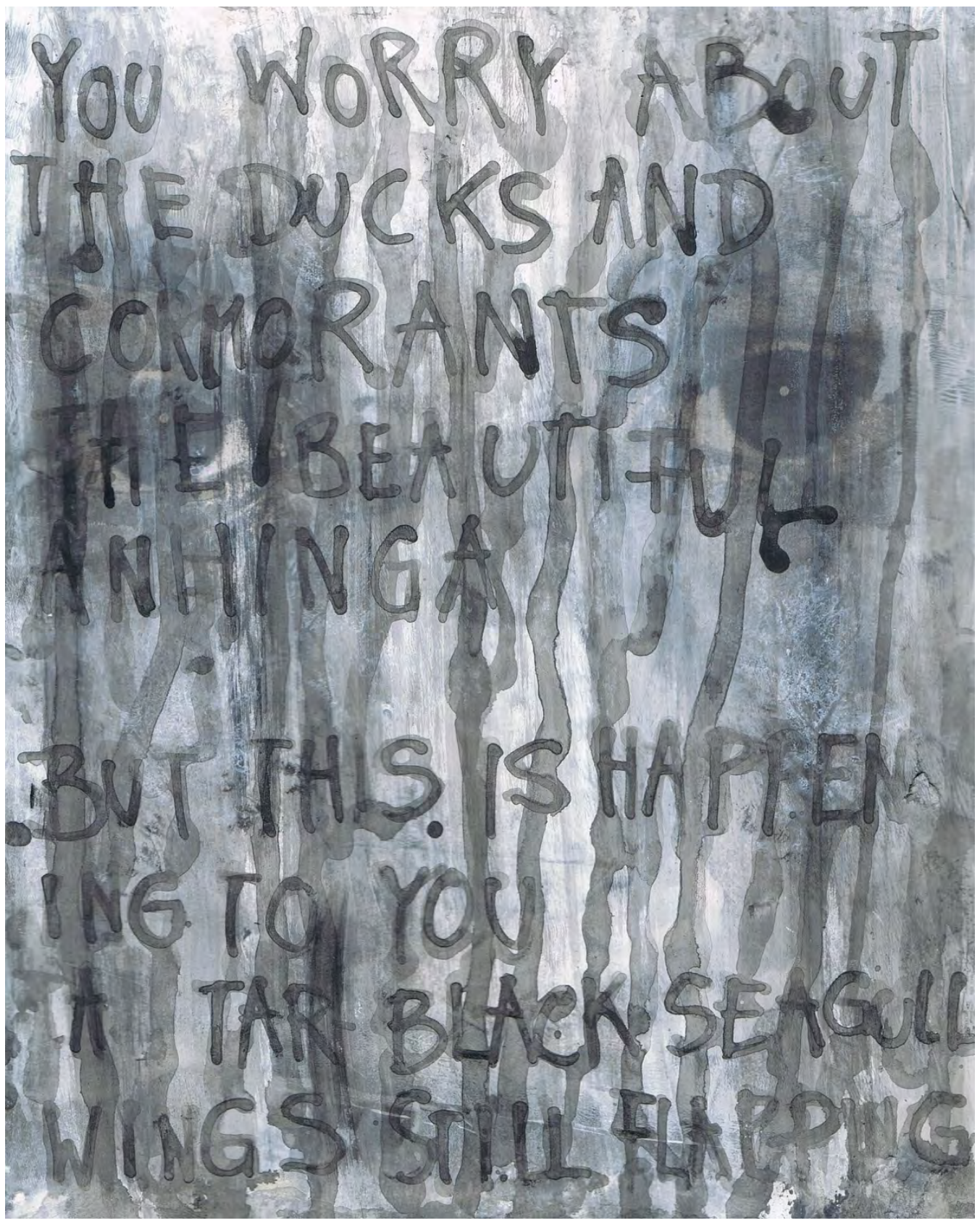




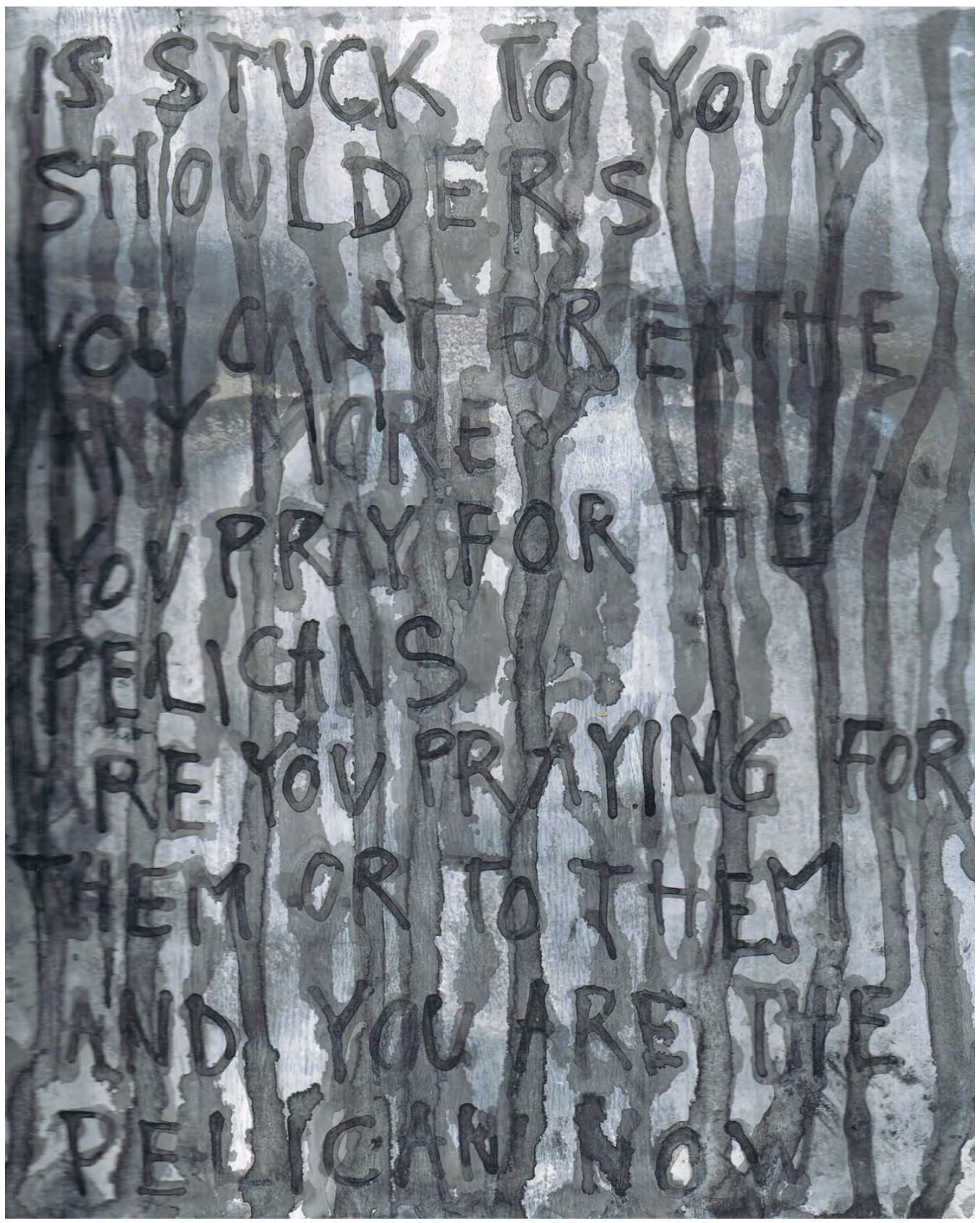




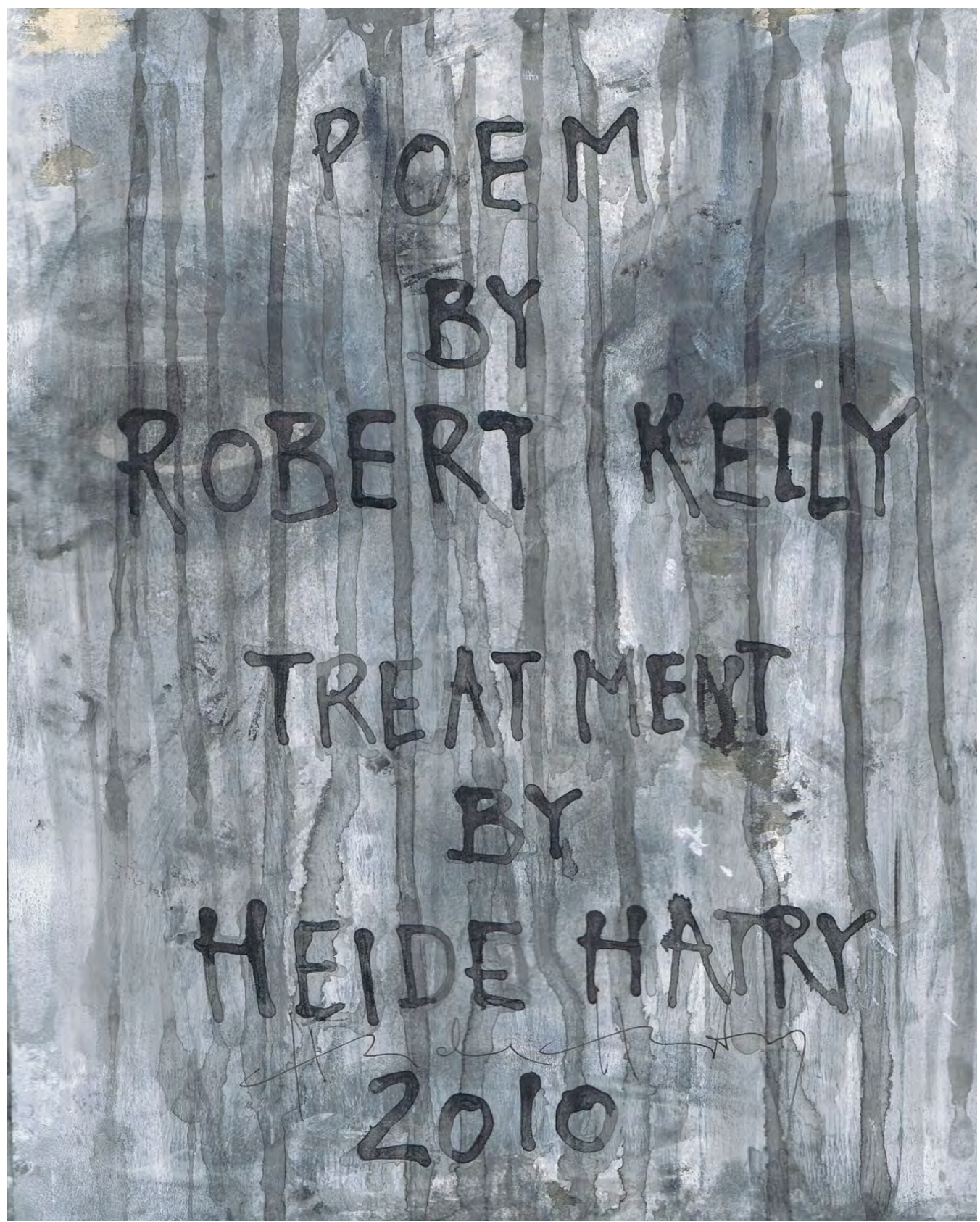




\section{Imagine It Thick In Your Own Hair}

Imagine it thick in your own hair

your eyes stuck shut

you gouge your scummy finger

in your nose to break a way for air

the black snot won't come out

you breathe a little, it whistles

it's in your eyes now, burning

and your ears are stuffed with sludge now too

you can't even hear yourself scream

and while you're screaming

you're thinking

if you can still think

that all this oil was leaf and meadow once,

turf and forest waving

millions and millions of years

all this was green life once

and even now the glistening black sludge

has a sheen of tree-brown in it

a sheen of green-

forget the pelicans and pretty ducks,

this is happening to you

you are the one

sealed in scum 
you feel your scalp aching your head trying to breathe did you know we breathe through the skin? only you can't, not any more, never again,

your skin belongs to business now this is the Midas touch of money they trade in your skin on the bourse, there is nothing left of the original you you still are screaming you make hardly any noise your throat is choked with oil you make only a little shushing noise like money changing hands

you still worry about the pelicans and the sea turtles you worry about the ducks and cormorants the beautiful anhinga but this is happening to you

a tar-black seagull

wings still flapping is stuck to your shoulders

you can't breathe any more you pray for the pelicans are you praying for them or to them and you are the pelican now

Robert Kelly 